\title{
Effect of different forage sources on performance and feeding behavior of Holstein calves
}

\author{
LI. Castells, ${ }^{*}$ A. Bach, ${ }^{*} \dagger$ G. Araujo, ${ }^{*}$ C. Montoro, ${ }^{*}$ and M. Terré ${ }^{\star 1}$ \\ *Department of Ruminant Production, Institut de Recerca i Tecnologia Agroalimentàries (IRTA), 08140 Caldes de Montbui, Spain \\ †Institució Catalana de Recerca i Estudis Avançats (ICREA), 08010 Barcelona, Spain
}

\begin{abstract}
One hundred seventy-nine Holstein male calves [44.7 $\mathrm{kg}$ of body weight (BW) and $8.3 \mathrm{~d}$ of age] participated in a series of 3 experiments to evaluate the effect of different forage sources on performance, apparent digestibility, and feeding behavior. Animals in each study were randomly assigned to 1 of 3 different dietary treatments: control (CON) calves were fed starter feed without any forage provision (this treatment was repeated in each of the 3 experiments), and the 2 other treatments consisted of the same starter feed plus a forage source: chopped alfalfa $(\mathrm{AH})$ or rye-grass hay $(\mathrm{RH})$ in the first study; chopped oat hay $(\mathrm{OH})$ or chopped barley straw (BS) in the second study; corn silage (CS) or triticale silage (TS) in the third study. All calves were offered $2 \mathrm{~L}$ of milk replacer (MR) at $12.5 \%$ dry matter (DM) twice daily via a bottle until $50 \mathrm{~d}$ of age, and 2 $\mathrm{L}$ of $\mathrm{MR}$ at $12.5 \% \mathrm{DM}$ during the week before weaning (57 d of age). The study finished when calves were $71 \mathrm{~d}$ old. Starter feed, MR, and forage intakes were recorded daily and BW weekly. Calves were individually housed and bedded with wood shavings. Compared with CON, animals receiving $\mathrm{OH}$, TS, and $\mathrm{BS}$ consumed more starter feed (0.88 vs. $1.14,1.17,1.06 \mathrm{~kg} / \mathrm{d}$, respectively) and had greater average daily gain $(0.72$ vs. $0.93,0.88$, $0.88 \mathrm{~kg} / \mathrm{d}$, respectively). Animals in treatments $\mathrm{RH}$, BS, CS, and TS consumed less forage $(51 \mathrm{~g} / \mathrm{d})$ than AH $(120 \mathrm{~g} / \mathrm{d})$ and $\mathrm{OH}(101 \mathrm{~g} / \mathrm{d})$ calves. Apparent organic matter, DM, and neutral detergent fiber digestibilities did not differ among treatments $(81.5,81.1$, and $54.4 \%$, respectively). Apparent crude protein digestibility was greater in $\mathrm{RH}, \mathrm{CS}$, and $\mathrm{AH}$ treatments than in $\mathrm{CON}$ (80.5 vs. $76.4 \%$, respectively). Compared with CON calves, animals in the $\mathrm{AH}$ treatment spent less time eating starter feed and lying, animals in $\mathrm{AH}$ and $\mathrm{RH}$ treatments spent more time ruminating, with odds ratios (OR) of 5.24 and 5.40, respectively. The AH and $\mathrm{RH}$ calves devoted less time to performing nonnutritive
\end{abstract}

Received March 30, 2011.

Accepted September 6, 2011.

${ }^{1}$ Corresponding author: marta.terre@irta.cat oral behaviors (OR: 0.38 and 0.34 , respectively), and TS calves tended to devote less time to perform nonnutritive oral behaviors (OR: 0.21) $1 \mathrm{~h}$ after being offered MR and solid feed. In conclusion, free-choice provision of a forage source to young calves improves feed intake and performance without impairing digestibilities of DM, organic matter, crude protein, and neutral detergent fiber, and, depending on forage source, reduces nonnutritive oral behaviors and stimulates rumination. Key words: calf, forage, performance

\section{INTRODUCTION}

Some controversy exists about the kind of solid feed that should be included in calf diets during the preweaning period. End-products resulting from fermentation of starter feeds in the rumen are predominantly butyrate and propionate. Butyrate has been reported to be the VFA that stimulates the greatest growth of rumen mucosa papillae (Sander et al., 1959; Warner, 1991). However, feeding only starter feed to preweaning calves may reduce ruminal pH (Beharka et al., 1998), decrease rumen motility (Clarke and Reid, 1974), and cause hyperkeratinization and clumping of ruminal papillae (Bull et al., 1965); thus, decreasing the ability of rumen mucosa to absorb nutrients (Hinders and Owen, 1965), especially if the starter feed is finely ground (Greenwood et al., 1997). On the other hand, forages stimulate the muscular layer of the rumen (Tamate et al., 1962), promote rumination (Hodgson, 1971; Phillips, 2004), maintain the integrity and healthiness of the rumen wall (Haskins et al., 1969; Suárez et al., 2007), and reduce behavioral problems (Phillips, 2004).

Provision of forage to young calves has not been recommended because it has been shown to reduce starter feed intake in individually housed calves (Phillips, 2004), impair rumen papillae development (Nocek and Kesler, 1980), and decrease BW and DM digestibility (Leibholz, 1975). Furthermore, cellulolytic activity in the rumen of young calves is not completely acquired until 3 to 4 wk after birth (Anderson et al., 1987; Sahoo et al., 2005), suggesting that forage consumed before 3 wk of age might not be properly digested. Interestingly, 
studies that provided a source of forage (chopped or long hay or straw) to calves younger than 2 wk of age reported improvements in performance (Thomas and Hinks, 1982; Phillips, 2004). In contrast, studies that limited starter feed intake or established a fixed forage to concentrate ratio in a pelleted diet reported different results depending on the ratio, the forage sources provided, and the ADF content of the diet (Stobo et al., 1966; Bartley, 1973; Leibholz, 1975; Block and Shellenberger, 1980; Beharka et al., 1998; Coverdale et al., 2004; Suárez et al., 2007).

Currently, starter feeds with relatively low NDF contents (16-18\%) are commonly used (Franklin et al., 2003; Lesmeister and Heinrichs, 2004; Kehoe et al., 2007) to optimize digestibility. In the literature, an array of forage sources (e.g., alfalfa hay, straw, grass hay, fresh grass, corn silage), chop lengths, and concentrate to forage ratios have been used, but no study has compared more than 2 forage sources under the same management conditions. Considering the need to optimize solid feed consumption of young calves, the objectives of this study were to evaluate the potential benefits of providing different forage sources, in a chopped form and offered separately from the starter feed, and determine the forage source that could best improve calf performance and welfare.

\section{MATERIALS AND METHODS}

\section{Animals and Treatments}

One hundred seventy-nine Holstein male calves were used in a series of 3 experiments. The first experiment was conducted with 60 calves $(43.8 \pm 5.7 \mathrm{~kg}$ of BW and $7.9 \pm 5.2 \mathrm{~d}$ of age), the second involved 59 calves $(46.1 \pm 5.0 \mathrm{~kg}$ of $\mathrm{BW}$ and $7.0 \pm 3.5 \mathrm{~d}$ of age $)$, and the third involved 60 calves $(44.1 \pm 5.4 \mathrm{~kg}$ of BW and $10.0 \pm 3.8 \mathrm{~d}$ of age). Calves were purchased from commercial farms, raised in the facilities of Torre Marimon (Caldes de Montbui, Spain), and managed according to the recommendations of the Animal Care Committee of Institut de Recerca i Tecnologia Agroalimentàries (IRTA). After arrival, calves were given a broad-spectrum antibiotic (Draxxin, tulathromycin, Pfizer Animal Health, Madrid, Spain) to prevent respiratory disease. Furthermore, calves were vaccinated against respiratory syncytial virus (Rispoval RS, Pfizer Animal Health) 3 $\mathrm{d}$ after arrival. Calves were allowed a 6 -d adaptation period to the new facilities, milk replacer (MR), and calf starter feed. Increasing levels of milk replacer DM concentration, starting at $10 \% \mathrm{DM}$, were offered until reaching the desired $12.5 \% \mathrm{DM}$ on the sixth day after arrival. Thus, the study was initiated when calves were $14.1 \pm 4.2 \mathrm{~d}$ old. Calves were housed in individual pens $(1.6 \times 1.0 \mathrm{~m})$ and bedded with sawdust. The 3 experiments followed the same management scheme. After the adaptation period, animals were weighed, and randomly distributed according to BW and age in 3 groups. Calves in the control (CON) group were fed a starter feed (Table 1) without any forage supplementation. Calves in the other 2 treatments had access to the same starter feed as those in CON treatment in one bucket, plus an additional bucket containing a forage source: chopped alfalfa hay $(\mathbf{A H})$ or rye-grass hay $(\mathbf{R H})$ in experiment 1, chopped oat hay $(\mathbf{O H})$ or chopped barley straw (BS) in experiment 2, and corn silage (CS) or triticale silage (TS) in experiment 3. Hay and straw forages were chopped with a foragechopper machine (Seko, Curtarolo, Italy) before being offered to calves. Nutrient composition and particle size distribution of the forages studied are given in Table 2. Particle size distribution of the forage sources was determined using 2 sieves with screen sizes of 20 and $8 \mathrm{~mm}$ diameter (Table 2). The CON treatment was repeated in each of the 3 experiments to account for the period effect and to allow comparison among all treatments. A commercial MR (25\% CP and $19.2 \%$ fat, Sprayfo Excellent 60, Sloten BV, Deventer, Holland) was offered in 2-L feeding bottles twice daily at 0700 and $1700 \mathrm{~h}$. Calves received $4 \mathrm{~L} / \mathrm{d}$ of $\mathrm{MR}$ at $12.5 \%$ DM dilution rate until $50 \mathrm{~d}$ of age. From 50 to $56 \mathrm{~d}$ of age, calves received only the morning feeding of $2 \mathrm{~L}$ at $12.5 \%$ DM. Animals were weaned at $57 \mathrm{~d}$ of age, and the study ended when the calves were $71 \mathrm{~d}$ old. Starter feed and forage were offered ad libitum $1 \mathrm{~h}$ after MR was consumed in 2 separate buckets throughout the study.

\section{Measurements and Sample Collection}

Starter feed, MR, and forage intakes were recorded daily on an individual basis. Calves were weighed weekly. The week after weaning (64 d of age), plastic bags were glued to 8 animals (randomly chosen) per treatment to determine apparent $\mathrm{DM}, \mathrm{OM}, \mathrm{CP}$, and NDF digestibility of the diet, as described elsewhere (Terré et al., 2007). During 5 consecutive days, all feces were collected and weighed. Bags were changed 4 times a day. Then, a subsample equivalent to $30 \%$ of total daily feces was obtained and dried at $60^{\circ} \mathrm{C}$ for $72 \mathrm{~h}$, and subsamples of the $5 \mathrm{~d}$ were composited by animal proportionally to the dry weight of the feces produced each day. Samples were ground to pass through a 1-mm screen (Cyclotech 1093 mill, Tecator, Hoganas, Sweden) and analyzed for DM, OM, CP, and NDF. Daily orts from forages were collected, composited for the 5 -d period, and processed similarly to fecal samples. Apparent nutrient digestibility was calculated as the 
Table 1. Ingredient and chemical composition of experimental starter feed

\begin{tabular}{lc}
\hline Item & $\begin{array}{c}\text { Composition, } \\
\text { \% of DM }\end{array}$ \\
\hline Ingredient & \\
Wheat & 20.0 \\
Corn & 15.0 \\
Barley & 11.2 \\
Sorghum & 12.0 \\
Soybean meal & 23.0 \\
Wheat middlings & 12.0 \\
Soybean hulls & 5.0 \\
Premix ${ }^{1}$ & 0.2 \\
Calcium carbonate & 0.5 \\
Dicalcium phosphate & 0.3 \\
Sodium chloride & 0.8 \\
Nutrient composition, \% of DM & \\
CP & 19.5 \\
NDF & 17.7 \\
ADF & 8.0 \\
Ash & 5.6 \\
\hline
\end{tabular}

${ }^{1}$ Premix composition: vitamin A 2,007,000 IU/kg; vitamin $\mathrm{D}_{3} 433,000$ $\mathrm{IU} / \mathrm{kg}$; vitamin $\mathrm{E}_{3} 685 \mathrm{mg} / \mathrm{kg}$; vitamin $\mathrm{B}_{1} 52 \mathrm{mg} / \mathrm{kg}$; vitamin $\mathrm{B}_{2} 197$ $\mathrm{mg} / \mathrm{kg}$; vitamin $\mathrm{B}_{6} 98 \mathrm{mg} / \mathrm{kg}$; vitamin $\mathrm{B}_{12} 0.76 \mathrm{mg} / \mathrm{kg}$; vitamin $\mathrm{K}_{3} 52$ $\mathrm{mg} / \mathrm{kg}$; nicotinic acid $656 \mathrm{mg} / \mathrm{kg}$; pantothenic acid $394 \mathrm{mg} / \mathrm{kg} ; \mathrm{Mn}$ $5,877 \mathrm{mg} / \mathrm{kg} ; \mathrm{Fe}$ 7,093 mg/kg; Cu 2,026 mg/kg; Co 46 mg/kg; Zn 8,112 $\mathrm{mg} / \mathrm{kg}$; I $304 \mathrm{mg} / \mathrm{kg}$; Se $46 \mathrm{mg} / \mathrm{kg}$.

quantity of nutrient consumed minus the quantity of nutrient defecated, divided by the quantity of nutrient consumed.

\section{Chemical Analysis}

Samples of MR were analyzed for DM $\left(24 \mathrm{~h}\right.$ at $\left.103^{\circ} \mathrm{C}\right)$, ash $\left(4 \mathrm{~h}\right.$ at $\left.550^{\circ} \mathrm{C}\right), \mathrm{N}$ content using method 988.05 of AOAC (1990) adapted for an automatic distiller Kjeldahl (Kjeltec Auto 1030 Analyzer, Tecator) with copper sulfate/selenium as a catalyst instead of copper sulfate/titanium dioxide, and ether extract using method 920.39 of AOAC (1990) using petroleum ether for distillation instead of diethyl ether (AOAC, 1990). Samples of starter feed and forages were analyzed for
DM, ash, and CP following the same methods described above, plus NDF with sodium sulfite and heat-stable a-amylase (Van Soest et al., 1991), and ADF following AOAC (1990) method 973.18.

To determine apparent digestibility of nutrients, samples of feces, starter feed, and forage orts were analyzed for DM, ash, and NDF as described above.

\section{Animal Behavior}

Behavior was monitored by direct observations for 10 animals randomly chosen within treatment once a week for 2 wk before and 2 wk after weaning. Animals were observed for $1 \mathrm{~h}$ immediately following the morning MR feeding and one additional hour after solid feed was weighed and offered during the 2 preweaning weeks. After weaning, calves were observed for 2 consecutive hours after being offered the solid feed. Therefore, total observation time per animal was $8 \mathrm{~h}$ for the entire monitoring period. Calves were observed every minute, and the observer recorded the occurrence of the following behaviors: lying (no chewing activity), standing (no chewing activity), eating starter feed, eating forage, ruminating (either lying or standing), and nonnutritive oral behaviors (when the animal licked any surface, tongue rolled, or consumed wood shavings).

\section{Statistical Analysis}

First, an ANOVA among CON treatments from the 3 different experiments was performed to confirm that responses to CON did not differ among periods, thus ensuring that data from the 3 experiments could be analyzed together.

Performance data were analyzed with a mixed-effects model for repeated measures. The statistical model included initial BW as a covariate, treatment, week of study, and their interaction as fixed effects, and animal

Table 2. Chemical composition and particle size of forages

\begin{tabular}{|c|c|c|c|c|c|c|}
\hline \multirow[b]{2}{*}{ Item } & \multicolumn{6}{|c|}{ Treatment $^{1}$} \\
\hline & $\mathrm{AH}$ & $\mathrm{RH}$ & $\mathrm{OH}$ & BS & $\mathrm{CS}$ & TS \\
\hline DM, $\%$ & 88.7 & 92.1 & 90.9 & 93.3 & 28.6 & 25.0 \\
\hline \multicolumn{7}{|l|}{ Composition, $\%$ of DM } \\
\hline $\mathrm{CP}$ & 16.6 & 6.8 & 8.4 & 4.2 & 8.6 & 7.5 \\
\hline $\mathrm{NDF}$ & 40.2 & 59.3 & 59.6 & 74.0 & 41.9 & 64.7 \\
\hline $\mathrm{ADF}$ & 30.2 & 35.1 & 31.8 & 42.5 & 25.2 & 42.3 \\
\hline Ash & 10.4 & 13.4 & 8.5 & 8.8 & 7.8 & 5.5 \\
\hline \multicolumn{7}{|l|}{ Particle size, \% } \\
\hline$>20 \mathrm{~mm}$ & 39.4 & 50.3 & 28.4 & 31.1 & 8.4 & 1.7 \\
\hline $8-20 \mathrm{~mm}$ & 17.1 & 24.5 & 27.2 & 33.4 & 31.6 & 50.5 \\
\hline$<8 \mathrm{~mm}$ & 43.5 & 25.2 & 44.4 & 35.5 & 60.0 & 47.8 \\
\hline
\end{tabular}

${ }^{1} \mathrm{AH}=$ alfalfa hay; $\mathrm{RH}=$ rye-grass hay; $\mathrm{OH}=$ oat hay; $\mathrm{BS}=$ barley straw; $\mathrm{TS}=$ triticale silage; $\mathrm{CS}=$ corn silage. 
Table 3. Performance and feed intake of calves supplemented with different forage sources or not supplemented (CON)

\begin{tabular}{|c|c|c|c|c|c|c|c|c|c|c|}
\hline \multirow[b]{2}{*}{ Item } & \multicolumn{7}{|c|}{ Treatment $^{1}$} & \multirow[b]{2}{*}{ SEM } & \multicolumn{2}{|c|}{$P$-value ${ }^{2}$} \\
\hline & $\mathrm{CON}$ & $\mathrm{AH}$ & $\mathrm{RH}$ & $\mathrm{OH}$ & BS & TS & $\mathrm{CS}$ & & $\mathrm{T}$ & $\mathrm{T} \times \mathrm{t}$ \\
\hline Initial BW, kg & 45.2 & 43.6 & 43.3 & 46.7 & 46.2 & 45.0 & 44.8 & 1.13 & 0.40 & - \\
\hline Final BW, $\mathrm{kg}$ & $84.5^{\mathrm{d}}$ & $86.4^{\mathrm{cd}}$ & $91.6^{\mathrm{ab}}$ & $96.1^{\mathrm{a}}$ & $93.2^{\mathrm{ab}}$ & $93.6^{\mathrm{ab}}$ & $89.8^{\mathrm{bc}}$ & 2.03 & $<0.001$ & - \\
\hline $\mathrm{ADG}, \mathrm{kg} / \mathrm{d}$ & $0.72^{\mathrm{c}}$ & $0.76^{\mathrm{bc}}$ & $0.84^{\mathrm{ab}}$ & $0.93^{\mathrm{a}}$ & $0.88^{\mathrm{a}}$ & $0.88^{\mathrm{a}}$ & $0.82^{\mathrm{ab}}$ & 0.038 & $<0.001$ & $<0.001$ \\
\hline \multicolumn{11}{|c|}{ Intake, $\mathrm{kg}$ of $\mathrm{DM} / \mathrm{d}$} \\
\hline Starter & $0.88^{\mathrm{cd}}$ & $0.76^{\mathrm{d}}$ & $0.99^{\mathrm{abc}}$ & $1.14^{\mathrm{ab}}$ & $1.06^{\mathrm{ab}}$ & $1.17^{\mathrm{a}}$ & $0.98^{\mathrm{bc}}$ & 0.028 & $<0.001$ & $<0.001$ \\
\hline Forage & 年 & $0.120^{\mathrm{a}}$ & $0.046^{\mathrm{b}}$ & $0.101^{\mathrm{a}}$ & $0.060^{\mathrm{b}}$ & $0.048^{\mathrm{b}}$ & $0.051^{\mathrm{b}}$ & 0.0198 & $<0.001$ & $<0.001$ \\
\hline $\mathrm{TDMI}^{3}$ & $1.29^{\mathrm{e}}$ & $1.37^{\mathrm{de}}$ & $1.46^{\mathrm{cd}}$ & $1.67^{\mathrm{a}}$ & $1.55^{\mathrm{abc}}$ & $1.64^{\mathrm{ab}}$ & $1.48^{\mathrm{bcd}}$ & 0.024 & $<0.001$ & $<0.001$ \\
\hline DMI, $\%$ of BW & $2.14^{\mathrm{d}}$ & $2.26^{\mathrm{cd}}$ & $2.36^{\mathrm{bc}}$ & $2.55^{\mathrm{a}}$ & $2.42^{\mathrm{abc}}$ & $2.54^{\mathrm{ab}}$ & $2.35^{\mathrm{c}}$ & 0.0004 & $<0.001$ & $<0.001$ \\
\hline Gain-to-feed ${ }^{4}$ & 0.5465 & 0.5417 & 0.5557 & 0.5508 & 0.5598 & 0.5370 & 0.5481 & 0.01260 & 0.82 & $<0.001$ \\
\hline
\end{tabular}

${ }^{\mathrm{a} e} \mathrm{e}$ Means within a row with different superscripts differ $(P<0.05)$.

${ }^{1} \mathrm{CON}=$ control; $\mathrm{AH}=$ alfalfa hay; $\mathrm{RH}=$ rye-grass hay; $\mathrm{OH}=$ oat hay; $\mathrm{BS}=$ barley straw; $\mathrm{TS}=$ triticale silage; $\mathrm{CS}=$ corn silage.

${ }^{2} \mathrm{~T}=$ treatment effect; $\mathrm{T} \times \mathrm{t}=$ interaction between treatment and time.

${ }^{3} \mathrm{TDMI}=$ total DMI (milk replacer, starter feed, and forage).

${ }^{4}$ Kilograms of BW gain/kg of TDMI.

and period as random effects. Due to the lack of normality, data from starter feed, forage, and total DM intake (TDMI) were root-square transformed. Least squares means presented herein for these 3 parameters correspond to nontransformed data, and SEM and $P$-values correspond to the results from the mixed-effects model using root-square transformed data. Apparent nutrient digestibility was analyzed with the same mixed-effects model described above but without the effect of week of study and the BW covariate.

Behavior data were summarized individually as the total time $(\mathrm{min})$ devoted to each monitored behavior before and after weaning $(2 \mathrm{~h}$ per wk and animal during $2 \mathrm{wk}$ before and $2 \mathrm{wk}$ after weaning; therefore $4 \mathrm{~h}$ per animal before and $4 \mathrm{~h}$ per animal after weaning). After that, a mixed-effects Poisson regression analysis including calf and period as random effects and treatment and time relative to weaning (before or after) as fixed effects was performed.

\section{RESULTS AND DISCUSSION}

\section{Performance}

Animal performance and feed consumption are presented in Table 3 . Increases $(P<0.001)$ equivalent to 33,29 , and $20 \%$ in starter feed intake were observed in $\mathrm{TS}, \mathrm{OH}$, and BS calves compared with those offered CON. However, calves in the AH treatment had similar starter feed intake to CON calves and consumed less starter feed than those offered other forage treatments. Starter feed intake of $\mathrm{RH}$ and $\mathrm{CS}$ calves was similar to $\mathrm{CON}, \mathrm{OH}$, and $\mathrm{BS}$ treatments, but greater than intake recorded on $\mathrm{AH}$ calves. Starter feed intake was increased $(P<0.001)$ when a forage source was offered (with the exception of $\mathrm{AH}$ ) compared with $\mathrm{CON}$ calves beginning at 29,36,43, and $50 \mathrm{~d}$ of age until the end of the study for TS, OH, BS, and RH, respectively (Figure $1)$.

Forage intake was greatest $(P<0.001)$ for calves fed $\mathrm{AH}$ and $\mathrm{OH}$ compared with the other treatments. Interestingly, $\mathrm{AH}$ and $\mathrm{OH}$ calves consumed similar amounts of forage, but the consumption of $\mathrm{AH}$ did not stimulate starter feed intake, whereas $\mathrm{OH}$ promoted a significant increase in starter feed intake (Table 3). In spite of the high forage intake of the $\mathrm{AH}$ treatment, TDMI of $\mathrm{AH}$ calves was similar to that of CON calves. Calves fed the $\mathrm{OH}$, TS and BS had the greatest $(P<0.001)$ TDMI. A large intake of $\mathrm{AH}$ was expected because voluntary intake of legumes is consistently reported to be greater (at equivalent stages of maturity) than that of grass forages (Colburn et al., 1968; Moseley and Jones, 1979). A relatively low silage consumption could be expected because of potential negative effects on intake of some fermentation end-products such as amines (Van Soest, 1982). On the other hand, the high $\mathrm{NDF}$ and ADF contents of BS and RH may have potentially limited forage intake. In the current study, a different response between animals offered grass and legume forages was observed. Offering a legume (AH) failed to improve TDMI and calf performance, whereas calves fed a grass forage showed an increased TDMI and thus performance. The small forage consumption in calves offered grasses may have improved the rumen environment, which in turn may have contributed to stimulation of starter feed intake, TDMI, and increased calf performance. Probably, these observations are due to differences in some properties between grasses and legumes such as a greater flow rate from the rumen for legumes compared with grasses (Moseley and Jones, 1979). In addition, greater pectin and lesser hemicellulose contents in legumes than in grasses might be 


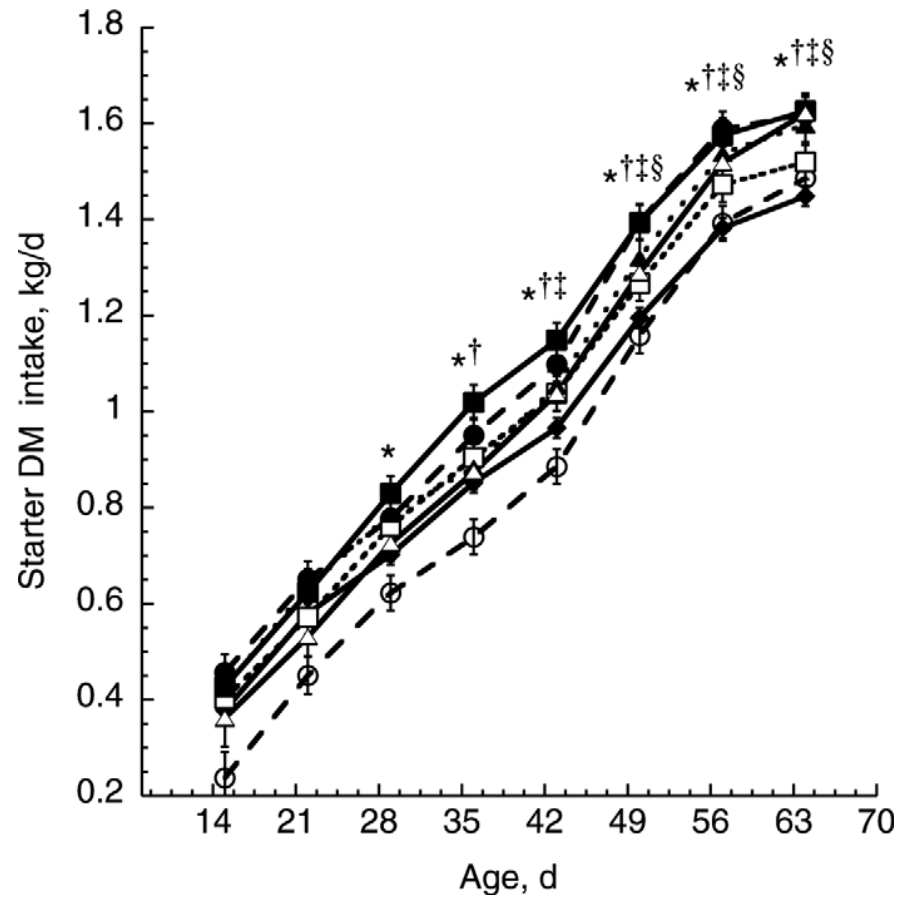

Figure 1. Evolution of starter feed intake as affected by forage supplementation: control (no forage supplementation; •), alfalfa hay $(\bigcirc)$, rye-grass hay $(\Delta)$, oat hay $(\bullet)$, barley straw $(\boldsymbol{\Lambda})$, corn silage $(\square)$, and triticale silage $(\mathbf{\square})$. For each time point, ${ }^{*}$ denotes significant differences $(P<0.05)$ between triticale silage and control, $\dagger$ denotes significant differences $(P<0.05)$ between oat hay and control, $\ddagger$ denotes significant differences $(P<0.05)$ between barley straw and control, and $\S$ denotes significant differences $(P<0.05)$ between rye-grass hay and control.

responsible for the contrasting results obtained with these 2 forage types.

Providing a chopped forage source, other than AH, to preweaning calves improved ADG $(P<0.001)$ compared with calves on the CON treatment. The greatest ADG were observed in animals offered $\mathrm{OH}, \mathrm{TS}$, and BS, with ADG ranging from 21 to $28 \%$ over those observed with CON calves. Calves in the RH and CS treatments had greater ADG than CON and similar to AH calves. Similar to the patterns observed in starter feed intake, ADG was affected $(P<0.001)$ by forage source (Figure 2 ). Calves receiving TS reached a greater ADG compared with CON starting at $29 \mathrm{~d}$ of study, those offered $\mathrm{OH}$ or $\mathrm{CS}$ at $43 \mathrm{~d}$, and calves offered BS or RH after $50 \mathrm{~d}$ of study. Even though the forages tested in the present study were chopped, they had different particle sizes, and these differences might have contributed to elicit the observed responses among treatments. To our knowledge, the only study evaluating the potential effect of particle size of forage in calves was conducted by Hodgson (1971), who concluded that the most influential factor promoting solid consumption was the ease with which the diet could be eaten by calves.

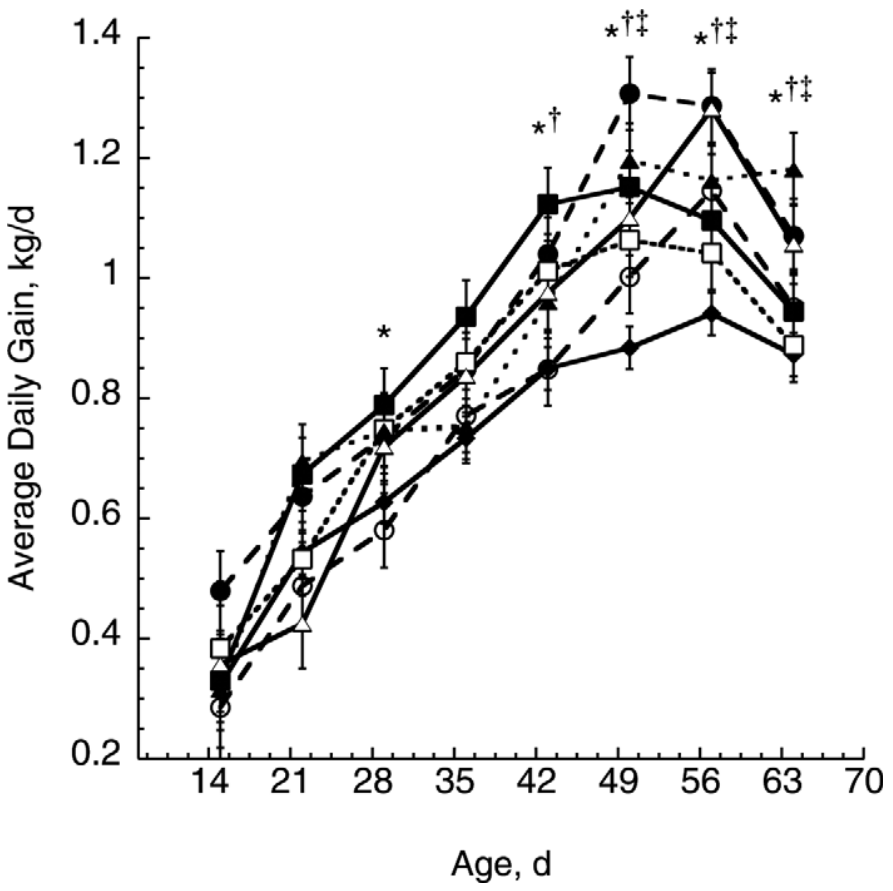

Figure 2. Evolution of average daily gain as affected by forage supplementation: control (no forage supplementation; $\bullet$ ), alfalfa hay $(\bigcirc)$, rye-grass hay $(\triangle)$, oat hay $(\bullet)$, barley straw $(\mathbf{\Lambda})$, corn silage $(\square)$, and triticale silage $(\mathbf{\square})$. For each time point, $*$ denotes significant differences $(P<0.05)$ between triticale silage and control, $\dagger$ denotes significant differences $(P<0.05)$ between oat hay and control, and $\ddagger$ denotes significant differences $(P<0.05)$ between barley straw and rye-grass hay and control.

Despite the changes observed in intake and performance with the provision of forages, no differences were observed in gain to feed ratio among treatments. This result would suggest that, contrary to common thought, forage consumption within the levels reported herein does not compromise nutrient utilization in young calves. However, several researchers (Coverdale et al., 2004; Suárez et al., 2007) did not observe differences in TDMI when part of the starter feed was substituted by roughage during the preweaning period. Suárez et al. (2007) established different forage to concentrate ratios (i.e., 70 concentrate: 30 straw; 70 concentrate:30 corn silage; 40 concentrate:60 corn silage), where the forage proportion was far greater than the ratio "chosen" by the calves in the present study when forage and starter feed were offered free-choice. For instance, in the current study, when forages were offered ad libitum and separately from the starter feed, calves in the $\mathrm{OH}$, $\mathrm{BS}, \mathrm{TS}, \mathrm{RH}$, and CS groups consumed diets with final forage:concentrate ratios of 8:92, 5:95, 4:96, 4:96, and $5: 95$, respectively. Therefore, the greater forage content in the diets studied by Suárez et al. (2007) compared with forage consumed voluntarily by calves in the current study may have masked the positive effect on stim- 
ulating starter feed intake when a grass forage source is provided to young calves. On the other hand, Coverdale et al. (2004) fed a forage to concentrate ratio similar to that observed with the $\mathrm{OH}$ treatment herein, but the total amount of solid feed offered during the preweaning period was limited. This probably hampered the potential positive effect of roughage to stimulate TDMI. Hill et al. (2008) found that in animals fed increasing percentages of hay in the starter feed, intake of starter feed, ADG, and feed efficiency linearly declined. However, Hill et al. (2008) mixed the forage source with the starter feed and thus calves were also forced to consume a predetermined fixed forage to concentrate ratio that was also greater than the ratio freely chosen by calves herein. The incorporation of between 10 and $25 \%$ of ground or chopped hay or straw into a complete starter feed is generally recommended for calves because it has been reported to increase DMI and ADG (Thomas and Hinks, 1982; Davis and Drackley, 1998). However, the current study illustrates that when forage and starter feed are offered separately, calves choose a proportion less than 10 to $25 \%$ of chopped forage, which improved calf performance.

Compared with that in CON, NDF consumption $(156 \mathrm{~g} / \mathrm{d})$ was greater $(P<0.05)$ in $\mathrm{OH}(293 \mathrm{~g} / \mathrm{d})$, BS $(258 \mathrm{~g} / \mathrm{d})$, TS $(248 \mathrm{~g} / \mathrm{d})$, CS $(208 \mathrm{~g} / \mathrm{d})$, and AH and RH $(173 \mathrm{~g} / \mathrm{d})$ calves. These differences in NDF consumption were mainly due to the inclusion of a forage source in the supplemented treatments. On the other hand, $\mathrm{CP}$ intake was similar among $\mathrm{CON}, \mathrm{AH}$, and $\mathrm{RH}$ treatments $(173 \mathrm{~g} / \mathrm{d})$. However, a greater $\mathrm{CP}$ intake was observed in calves fed $\mathrm{OH}$, BS, and TS treatments compared with CON (235 vs. $171 \mathrm{~g} / \mathrm{d}$, respectively). Differences in CP intake among treatments were due mainly to variations in starter feed intake. The proportion of total NDF relative to the total diet consumed when a forage source was provided relative to $\mathrm{CON}$ was $3.4,1.96,3.26,2.92,0.92$, and 2.29 percentage units for $\mathrm{AH}, \mathrm{RH}, \mathrm{OH}, \mathrm{BS}, \mathrm{CS}$, and TS calves, respectively. In contrast, $\mathrm{CP}$ content of the total diet consumed relative to $\mathrm{CON}$ decreased $0.2,0.5,1,0.9,0.4$, and 0.6 percent- age units for $\mathrm{AH}, \mathrm{RH}, \mathrm{OH}, \mathrm{BS}, \mathrm{CS}$, and TS treatments, respectively.

\section{Apparent Nutrient Digestibility}

Total-tract apparent DM, OM, and NDF digestibilities did not differ across treatments (Table 4), which may explain the absence of differences in feed efficiency among treatments (Table 3). However, CP digestibility was greater $(P<0.05)$ in $\mathrm{AH}, \mathrm{RH}$, and $\mathrm{CS}$ treatments compared with $\mathrm{CON}, \mathrm{OH}$, and $\mathrm{BS}$, with TS being in an intermediate position similar to all treatments. Apparent nutrient digestibilities observed herein are in the range previously reported in weaned calves (Terré et al., 2007; Hill et al., 2010). Generally, highfiber diets (Porter et al., 2007; Zanton and Heinrichs, 2009) and high DMI (Zanton and Heinrichs, 2008) compromise diet digestibility. However, in the present study, DM, OM, and NDF digestibilities observed in calves supplemented with a forage source were similar to those observed in forage-deprived calves, and CP digestibility of free-choice forage treatments was greater or similar to, but never lower than, that observed in CON animals. In contrast to the current study, Porter et al. (2007) reported that DM digestibility in animals fed high-fiber diets (27\% NDF) was lower than that of calves offered low-fiber diets (20\% NDF). The decrease in NDF digestibility reported by Porter et al. (2007) might have been due to greater NDF contents of the total diet consumed by calves than those used in the current study. In the current study, the lack of a decrease in NDF apparent digestibility when offering chopped forages to calves could be associated with a potential improvement of the rumen environment. On the other hand, the improvements of $\mathrm{CP}$ digestibility observed with $\mathrm{RH}, \mathrm{CS}$, and $\mathrm{AH}$ treatments might be related to the lower TDMI compared with $\mathrm{OH}, \mathrm{BS}$, and TS treatments. In fact, CP apparent digestibility relative to that in CON calves did not improve in $\mathrm{OH}, \mathrm{BS}$, and TS calves, probably because a potentially increased passage rate.

Table 4. Total-tract nutrient apparent digestibility of calves supplemented with different forage sources or not supplemented (CON)

\begin{tabular}{lcccccccccc}
\hline & \multicolumn{9}{c}{ Treatment $^{1}$} \\
\cline { 2 - 6 } Digestibility, \% & CON & AH & RH & OH & BS & TS & CS & SEM & $P$-value \\
\hline DM & 80.0 & 81.3 & 83.0 & 80.7 & 80.0 & 81.2 & 81.2 & 1.03 \\
OM & 80.5 & 82.1 & 83.5 & 81.1 & 80.4 & 81.5 & 81.6 & 1.02 & 0.43 \\
NDF & 50.0 & 55.8 & 57.6 & 54.5 & 52.8 & 58.0 & 52.5 & 2.85 \\
CP & $76.4^{\mathrm{b}}$ & $79.8^{\mathrm{a}}$ & $81.0^{\mathrm{a}}$ & $76.3^{\mathrm{b}}$ & $75.8^{\mathrm{b}}$ & $79.1^{\mathrm{ab}}$ & $80.7^{\mathrm{a}}$ & 1.30 & 0.21 \\
\hline
\end{tabular}

${ }^{\mathrm{a}, \mathrm{b}}$ Means within a row with different superscripts differ $(P<0.05)$.

${ }^{1} \mathrm{CON}=$ control; $\mathrm{AH}=$ alfalfa hay; $\mathrm{RH}=$ rye-grass hay; $\mathrm{OH}=$ oat hay; $\mathrm{BS}=$ barley straw; $\mathrm{TS}=$ triticale silage; $\mathrm{CS}=$ corn silage. 
Table 5. Total time devoted to perform different behaviors during $8 \mathrm{~h}$ of observations ${ }^{1,2}$

\begin{tabular}{|c|c|c|c|c|c|c|c|}
\hline \multirow[b]{2}{*}{ Behavior } & \multicolumn{7}{|c|}{ Treatment $^{3}$} \\
\hline & $\mathrm{CON}$ & $\mathrm{AH}$ & $\mathrm{RH}$ & $\mathrm{OH}$ & BS & CS & TS \\
\hline Standing, min & 155.6 & $\begin{array}{r}181.5 \\
(0.85)\end{array}$ & $\begin{array}{c}154.3 \\
(0.88)\end{array}$ & $\begin{array}{r}184.3 \\
(0.98)\end{array}$ & $\begin{array}{r}176.9 \\
(1.15)\end{array}$ & $\begin{array}{l}192.4 \\
(1.30)\end{array}$ & $\begin{array}{l}192.7 \\
(1.17)\end{array}$ \\
\hline Lying, min & 272.3 & $\begin{array}{l}200.7 \\
(0.74)^{* *}\end{array}$ & $\begin{array}{c}255.3 \\
(0.91)\end{array}$ & $\begin{array}{c}230.1 \\
(0.73)\end{array}$ & $\begin{array}{c}224.8 \\
(0.76)\end{array}$ & $\begin{array}{c}205.7 \\
(0.77)\end{array}$ & $\begin{array}{c}221.6 \\
(0.86)\end{array}$ \\
\hline Eating starter, min & 15.3 & $\begin{array}{l}16.9 \\
(0.38) * *\end{array}$ & $\begin{array}{l}11.9 \\
(0.77)\end{array}$ & $\begin{array}{l}12.4 \\
(1.10)\end{array}$ & $\begin{array}{c}9.0 \\
(0.94)\end{array}$ & $\begin{array}{l}14.3 \\
(1.39)\end{array}$ & $\begin{array}{l}17.2 \\
(0.86)\end{array}$ \\
\hline Eating forage, min & - & $\begin{array}{l}23.1 \\
(1.00)\end{array}$ & $\begin{array}{l}9.2 \\
(0.97)\end{array}$ & $\begin{array}{l}8.8 \\
(0.75)\end{array}$ & $\begin{array}{l}12.7 \\
(1.70)\end{array}$ & $\begin{array}{l}11.4 \\
(1.93)\end{array}$ & $\begin{array}{l}8.1 \\
(0.96)\end{array}$ \\
\hline Ruminating, min & 15.7 & $\begin{array}{l}45.0 \\
(5.24)^{* *}\end{array}$ & $\begin{array}{l}35.0 \\
(5.40)^{* *}\end{array}$ & $\begin{array}{l}32.7 \\
(2.92)\end{array}$ & $\begin{array}{l}49.8 \\
(1.40)\end{array}$ & $\begin{array}{l}43.2 \\
(1.52)\end{array}$ & $\begin{array}{l}22.9 \\
(2.32)\end{array}$ \\
\hline $\mathrm{NNOB},{ }^{4} \min$ & 21.1 & $\begin{array}{l}12.8 \\
(0.38) * *\end{array}$ & $\begin{array}{l}14.3 \\
(0.34)^{* *}\end{array}$ & $\begin{array}{l}11.7 \\
(0.79)\end{array}$ & $\begin{array}{l}6.8 \\
(1.34)\end{array}$ & $\begin{array}{l}13.0 \\
(0.58)\end{array}$ & $\begin{array}{l}17.5 \\
(0.21)^{*}\end{array}$ \\
\hline
\end{tabular}

${ }^{1}$ Observations were conducted between 2 wk before and 2 wk after weaning by calves offered a free choice of forage.

${ }^{2}$ The respective probability of each behavior performed by the forage-supplemented calves relative to those performed by forage-deprived calves $(\mathrm{CON})$ is shown (odds ratio in parentheses).

${ }^{3} \mathrm{CON}=$ control; $\mathrm{AH}=$ alfalfa hay; $\mathrm{RH}=$ rye-grass hay; $\mathrm{OH}=$ oat hay; $\mathrm{BS}=$ barley straw; $\mathrm{TS}=$ triticale silage; $\mathrm{CS}=$ corn silage.

${ }^{4}$ Nonnutritive oral behavior.

${ }^{*} P<0.10 ;{ }^{* *} P<0.05$.

\section{Animal Behavior}

Table 5 depicts the length of time and the odds ratios for each behavioral occurrence (compared with CON treatment) during $8 \mathrm{~h}$ of observations conducted during 2 wk before and 2 wk after weaning. No differences were found in time standing and time devoted to consuming forage among treatments. However, AH calves spent less $(P<0.001)$ time eating starter feed and lying without chewing activity $(P<0.05)$ than CON animals. The differences in lying behavior between $\mathrm{AH}$ and CON treatments could be explained by the fact that AH calves spent more time ruminating, which mainly occurs while lying, and eating forage, which did not occur in CON calves. Calves in the $\mathrm{AH}$ and $\mathrm{RH}$ treatments devoted more $(P<0.001)$ time to ruminating compared with CON calves. A reduction of ruminating activity was previously observed when forage was not offered (Hodgson, 1971; Phillips, 2004; Martin et al., 2006). Therefore, the increase in time devoted to rumination in $\mathrm{AH}$ and $\mathrm{RH}$ treatments relative to $\mathrm{CON}$ may be due to having access to a forage source; however, no differences were found in the other forage treatments. It is probable that the observation sessions were too short to allow differences to be detected among all treatments relative to $\mathrm{CON}$.

Calves in the $\mathrm{AH}$ and $\mathrm{RH}$ groups devoted less $(P<$ 0.01 ) time to perform nonnutritive oral behaviors, and TS calves tended $(P=0.06)$ to perform less nonnutritive oral behaviors than CON calves. The reduction of nonnutritive oral behavior when $\mathrm{AH}, \mathrm{RH}$, and TS were offered to calves is in accordance with the observations by Redbo and Nordblad (1997) and Phillips (2004), who reported that a restrictive allowance of roughage has a considerable effect on the number of bouts and length of oral stereotypies in heifers.

Although starter feed intake did not differ between $\mathrm{CON}$ and $\mathrm{AH}$ calves, $\mathrm{AH}$ animals devoted less time to eating starter feed during the observation sessions. Two explanations are proposed: either $\mathrm{AH}$ calves divided their eating behavior between consuming starter feed and consuming forage, or a hypothetical increase in eating rate occurred for $\mathrm{AH}$ compared with $\mathrm{CON}$ calves.

\section{CONCLUSIONS}

Generally, the provision of chopped grass hays or grass silages improved ADG and TDMI in preweaned calves without impairing nutrient digestibility and gain to feed ratio. However, these benefits were not observed when chopped alfalfa hay was offered. Consequently, the greatest starter feed intake and best performances were obtained when chopped oat hay, chopped barley straw, or triticale silage was offered ad libitum to young calves from 2 wk of life to weaning.

\section{ACKNOWLEDGMENTS}

We thank the Instituto Nacional de Investigación y Tecnología Agraria y Alimentarias for the financial support of this project (RTA2008-00031-00-00). We also thank Joan Suriñach, Jordi Casino, Pep Llauger, Guillem Velázquez, and Giovanni Pirisino (from Diputació de Barcelona and IRTA at Torre Marimon facilities) for their help with calf management. 


\section{REFERENCES}

Anderson, K. L., T. G. Nagaraja, J. L. Morrill, T. B. Avery, S. J. Galitzer, and J. E. Boyer. 1987. Ruminal microbial development in conventionally or early-weaned calves. J. Anim. Sci. 64:12151226 .

AOAC. 1990. Official Methods of Analysis. 15th ed. Association of Official Analytical Chemists, Arlington, VA.

Bartley, E. E. 1973. Effects of a self-fed pelleted mixture of hay and calf starter on the performance of young dairy calves. J. Dairy Sci. 56:817-820.

Beharka, A. A., T. G. Nagaraja, J. L. Morrill, G. A. Kennedy, and R. D. Klemm. 1998. Effects of form of the diet on anatomical, microbial and fermentative development of the rumen of neonatal calves. J. Dairy Sci. 81:1946-1955.

Block, E., and P. R. Shellenberger. 1980. Woodpulp fines or corn silage as roughages in complete rations or a pelleted complete ration for young dairy replacements from birth through 18 weeks of age. J. Dairy Sci. 63:2060-2070.

Bull, L. S., L. J. Bush, J. D. Friend, B. Harris Jr., and E. W. Jones. 1965. Incidence of ruminal parakeratosis in calves fed different rations and its relation to volatile fatty acid absorption. J. Dairy Sci. 48:1459-1466.

Clarke, R. T. J., and C. S. W. Reid. 1974. Foamy bloat of cattle. A review. J. Dairy Sci. 57:753-785.

Colburn, M. W., J. L. Evans, and C. H. Ramage. 1968. Ingestion control in growing ruminant animals by the components of cell-wall constituents. J. Dairy Sci. 51:1458-1464.

Coverdale, J. A., H. D. Tyler, J. D. Quigley III, and J. A. Brumm. 2004. Effect of various levels of forage and form of diet on rumen development and growth in calves. J. Dairy Sci. 87:2554-2562.

Davis, C. L., and J. K. Drackley. 1998. The Development Nutrition and Management of the Young Calf. Iowa State University Press, Ames.

Franklin, S. T., D. M. Amaral-Philips, J. A. Jackson, and A. A. Campbell. 2003. Health and performance of Holstein calves that suckled or were hand-fed colostrum and were fed one of three physical forms of starter. J. Dairy Sci. 86:2145-2153.

Greenwood, R. H., J. L. Morrill, E. C. Titgemeyer, and G. A. Kennedy. 1997. A new method of measuring diet abrasion and its effect on the development of the forestomach. J. Dairy Sci. 80:2534-2541.

Haskins, B. R., M. B. Wise, H. B. Craig, T. N. Blumer, and E. R. Barrack. 1969. Effects of adding low levels of roughage or roughage substitutes to high energy rations of fattening steers. J. Anim. Sci. 29:345-353.

Hill, T. M., H. G. Bateman II, J. M. Aldrich, and R. L. Schlotterbeck. 2008. Effects of the amount of chopped hay or cottonseed hulls in a textured calf starter on young calf performance. J. Dairy Sci. 91:2684-2693.

Hill, T. M., H. G. Bateman II, J. M. Aldrich, and R. L. Schlotterbeck. 2010. Effects of milk replacer program on digestion of nutrients in dairy calves. J. Dairy Sci. 93:1105-1115.

Hinders, R. G., and F. G. Owen. 1965. Relation of ruminal parakeratosis development to volatile fatty acid absorption. J. Dairy Sci. 48:1069-10738

Hodgson, J. 1971. The development of solid food intake in calves. 1. The effect of previous experience of solid food, and the physical form of diets, on the development of food intake after weaning. Anim. Prod. 13:15-24.

Kehoe, S. I., C. D. Dechow, and A. J. Heinrichs. 2007. Effects of weaning age and milk feeding frequency on dairy calf growth, health and rumen parameters. Livest. Sci. 110:267-272.
Leibholz, J. 1975. Ground roughage in the diet of the early-weaned calf. Anim. Prod. 20:93-100.

Lesmeister, K. E., and A. J. Heinrichs. 2004. Effects of corn processing on growth characteristics, rumen development, and rumen parameters in neonatal dairy calves. J. Dairy Sci. 87:3439-3450.

Martin, C., L. Brossard, and M. Doreau. 2006. Mechanisms of appearance of ruminal acidosis and consequences on physiopathology and performances. Prod. Anim. 19:93-107.

Moseley, G., and J. R. Jones. 1979. Some factors associated with the difference in nutritive value of artificially dried red clover and perennial ryegrass for sheep. Br. J. Nutr. 42:139-147.

Nocek, J. E., and E. M. Kesler. 1980. Growth and rumen characteristics of Holstein steers fed pelleted or conventional diets. J. Dairy Sci. 63:249-254.

Phillips, C. J. C. 2004. The effects of forage provision and group size on the behavior of calves. J. Dairy Sci. 87:1380-1388.

Porter, J. C., R. G. Warner, and A. F. Kertz. 2007. Effect of fiber level and physical form of starter on growth and development of dairy calves fed no forage. Prof. Anim. Sci. 23:395-400.

Redbo, I., and A. Nordblad. 1997. Stereotypies in heifers are affected by feeding regime. Appl. Anim. Behav. Sci. 53:193-202.

Sahoo, A., D. N. Damra, and N. N. Pathak. 2005. Pre- and postweaning attributes in faunated and ciliate-free calves fed calf starter with or without fish meal. J. Dairy Sci. 88:2027-2036.

Sander, E. G., R. G. Warner, H. N. Harrison, and J. K. Loosli. 1959. The stimulatory effect of sodium butyrate and sodium propionate on the development of rumen mucosa in the young calf. J. Dairy Sci. 42:1600-1605.

Stobo, I. J. F., J. H. B. Roy, and H. J. Gaston. 1966. Rumen development in the calf. 1. The effect of diets containing different proportions of concentrates to hay on rumen development. Br. J. Nutr. 20:171-188

Suárez, B. J., C. G. Van Reenen, N. Stockhofe, J. Dijkstra, and W. J. J. Gerrits. 2007. Effect of roughage source and roughage to concentrate ratio on animal performance and rumen development in veal calves. J. Dairy Sci. 90:2390-2403.

Tamate, H., A. D. McGilliard, N. L. Jacobson, and R. Getty. 1962. Effect of various diets on the anatomical development of the stomach in the calf. J. Dairy Sci. 45:408-420.

Terré, M., M. Devant, and A. Bach. 2007. Effect of level of milk replacer fed to Holstein calves on performance during the preweaning period and starter digestibility at weaning. Livest. Sci. 110:82-88.

Thomas, D. B., and C. E. Hinks. 1982. The effect of changing the physical form of roughage on the performance of the early-weaned calf. Anim. Prod. 35:375-384.

Van Soest, P. J. 1982. Page 344 in Nutritional Ecology of the Ruminant. Cornell University Press, Ithaca, NY.

Van Soest, P. J., J. B. Robertson, and B. A. Lewis. 1991. Methods for dietary fiber, neutral detergent fiber, and nonstarch polysaccharides in relation to animal nutrition. J. Dairy Sci. 74:3583-3597.

Warner, R. G. 1991. Nutritional factors affecting the development of a functional ruminant-A historical perspective. Pages 1-12 in Proc. Cornell Nutr. Conf. Cornell, University, Ithaca, NY.

Zanton, G. I., and A. J. Heinrichs. 2008. Rumen digestion and nutritional efficiency of dairy heifers limit-fed a high forage ration to four levels of dry matter intake. J. Dairy Sci. 91:3579-3588.

Zanton, G. I., and A. J. Heinrichs. 2009. Digestion and nitrogen utilization in dairy heifers limit-fed a low or high forage ration at four levels of nitrogen intake. J. Dairy Sci. 92:2078-2094. 